\title{
THE GRAFFITI ART AND THE DISCOVER OF THE KEITH HARING'S MURAL IN AMSTERDAM
}

\section{LA GRAFFITI ART E LA SCOPERTA DEL MURALES DI KEITH HARING AD AMSTERDAM}

\author{
Caterina Soliani \\ (Istituto di Restauro Delle Marche, Academy of Fine Arts of Macerata, Italy) \\ caterina.soliani@live.it
}

Recibido: 22 de mayo 2020 / Aceptado: 03 de septiembre 2020

\begin{abstract}
The purpose of this work is to contribute to the continuous growth of the art world (Street Art in particular) and to discuss how it is essential for the discovery of artists. These artists have been pioneers and forerunners of new pictorial techniques, freeing creative and psychological flair, and combining the latter with the artistic technology that promises great things despite limited materials.
\end{abstract}

The intention of this article is to consider the elements of artistic expression that are less commonly subject to discussion, such as the world of Street Art. This form of artwork has not always been understood or accepted, with street artists waiting for the opportune moment to express the narrative, experiences, and emotions of society through their artwork, a power that unites sentiment and encourages change.

It is art which affects the community, the population and society. It is designed above all others to become part of the collective memory through violence of image and colour.

This project led me to come into contact with one of the many artistic artefacts of the Street Art movement, the Keith Haring's mural in Amsterdam, a piece that makes me. understand and appreciate the problems inherent to these type of works, simple, synthetic, but never simplistic.

Therefore, a project, a study and a restoration hypothesis were conducted on one of the many works by Haring. The purpose of this was to shed light once again on the 
mural made in 1986 by the artist, situated in the Groothandeles Market of Amsterdam. No longer visible for thirty years, the mural was covered by insulation panels placed two years after its creation.

With professors Antonio Rava and William Shank, the association Keith Haring Foundation of New York, the Stedelijk Museum of Amsterdam, in collaboration with the gallery Vroom \& Varossieau, specialised in road art, on 8 June, the large metal sheet panels were removed and one of the greatest murals by Haring could once again be admired.

Keywords: Keith Haring, Amsterdam, Murales, 1866, Stedelijk Museum, Street Art

Riassunto: Lo scopo di questo elaborato è atto alla divulgazione del continuo crescere del mondo dell'Arte (in particolare della Street Art) e di come esso sia di fondamentale importanza per scoprire artisti che, nei loro elaborati, sono stati pionieri e precursori di nuove tecniche pittoriche, liberando l'estro creativo e psicologico ed unendo quest'ultimo alla tecnologia artistica che si prometteva immortale e capace di poter dare vita a grandi cose con limitati materiali.

L'intento di questo articolo è far scoprire elementi ed immagini non ampiamenti trattati, quali appunto il mondo della Street Art. Un'arte non sempre capita ed accettata che ha saputo e dovuto aspettare il momento giusto per esplodere in tutta la sua potenza narrativa e conflittuale, con episodi che riguardano la comunità, la popolazione ed il sociale. Ideata soprattutto per entrare a far parte della memoria collettiva con violenza di immagine e di colore.

Il progetto mi ha portata a toccare con mano uno dei tanti manufatti artistici del movimento della Street Art, Il murales di Keith Haring ad Amsterdam, facendomi capire, apprezzare e comprendere le problematiche intrinseche a questo tipo di opere, semplici e sintetiche ma mai semplicistiche.

È stato quindi condotto un progetto, uno studio ed un'ipotesi di restauro su di una delle tante opere lasciatoci da Haring. Quest'ultimo ha avuto come obbiettivo quello di portare nuovamente alla luce il murales realizzato nel 1986 dall'artista e situato all'interno del Groothandeles Market di Amsterdam. Non più visibile da trent'anni, l'opera era coperta da pannelli isolanti posti due anni dopo la sua realizzazione. 
Con i Professori Antonio Rava e William Shank, l'associazione Keith Haring Foundation di New York, lo Stedelijk Museum di Amsterdam e con la galleria Vroom \& Varossieau specializzata in arte di strada, 1'8 Giugno 2018, i grandi pannelli di lamiera metallica sono stati tolti ed è stato nuovamente possibile ammirare uno dei più grandi murales di Haring.

Parole chiave: Keith Haring, Amsterdam, Murales, 1866, Stedelijk Museum, Street Art

\section{The origin of urban art}

We are in 1967 and a young boy from Brewerytown, Philadelphia, decides to start writing his name on all the walls of the city. His name is Darryl McCray, better known as Cornbread. He doesn't know it yet, but his murals will trigger, in the following years, an artistic revolution made of ethnic, social, political and cultural names and references that will be called street art.

Born in troubled years, street art originates and grows in the poorest and most problematic neighborhoods of New York City. Harlem, South Bronx, Washington Heights, Brooklyn, Philadelphia are just some of the places that have become open-air galleries, grown like a Babel with a personal and intrinsic beauty.

According to Alessandro Riva (2007, pp. 30-31), this is how the subway of New York witnessed a real burst of tags. The underground transport system was literally invaded by names that, with the violence of their distinguishing traits, were waiting for the right opportunity to get out of the greyness of anonymity. And that opportunity came.

On July 21st of 1971, Taki 183 (183rd Street between Audubon and Amsterdam Avenue) was the subject of an article in the New York Times entitled "Taki 183 Spawn Pen Pals". From this moment on, Taki 183 represented a fertile ground for the dissemination and spread of the phenomenon we now call street art. With their tags, writers begin to fill the horror vacui of the metropolitan city. Their aim is not only to gain visibility with simple signatures, but to bring their ideals, their opinions in as many places as possible, or just to remind the world of their existence. The favorite places for this visual "bombing", in addition to the typical walls and facades, are any sort of means of transport that could spread and disseminate this new possibility of making art. 
According to Alessandro Barbieri Deva and Alessandro Mininno (2009), the MTA (Metropolitan Transition Authority) with its 466 stops, becomes a giant communication system connecting writers from distant neighborhoods and enabling them to have a high visibility on a large scale; almost like a billboard in the middle of Time Square. Street art begins to change, there is a stylistic research of the most complex letters and it is believed that Lonny Wood, also known as Phase II, invented the "bubble letters", or "softies", letters with strongly rounded and soft shapes.

From this moment on, graffiti is no longer perceived as vandalism, rather as a form of art with its own principles and rules to be respected. It is not easy to understand how street art became so successful. However, this article from the New York Magazine, written by Richard Goldstein (1973) and entitled "The Graffiti 'Hit' Parade", provides a good explanation:

\section{«THE GRAFFITI 'HIT’ PARADE}

“...It gets bigger and brighter. In recognition of this grand graffiti conquest of the subways, the Taki Award are inaugurated..."

The law prohibits it, scrubbers keep scrubbing it, the brass keep blasting it, but the graffiti underground parade goes on and on, getting bigger and brighter every day. Virtually all of the city's 6.802 subway cars have been "hit" by the irrepressible graffiti artists who have graduated from simple identification scribbles to what they call Grand Designs and Masterpieces.

The descendants of Taki 183-that ubliquitous name-signer who launched a thousand feltpen pals three years ago - now work with a battery of spray paints and multi-size markers, producing works of colossal scale and juicy hues. In recognition of this grand graffiti conquest of the subways, New York Magazine inaugurates the Taki Awards (henceforth known as T.A.s) and shows the winner on these pages. [...] » (Goldstein, 1973, pp.3034)

The title is a pun. 'Hit Parade' is a different and new way to draw attention to this neo-movement. Richard Goldstein replaced the word "tag" with the word "hit". Such a decision should not be taken for granted at all, since the hit parade is by definition the ranking of the most successful songs, established according to sales over a given period 
of time. Also, the tag, in this context, can be defined as the top of the charts of something that is changing, something new, that is sold for free in public spaces.

And this is how this large outdoor showroom wants to become "legitimate".

In 1974, Jack Palsinger founds NOGA "Nation Organization of Graffiti Artist" by donating a huge abandoned building to all the writers, creating a legitimate space to claim that each of them needed to be visible and important to others. According to Barbero Luca Maria and Iovane Giovanni (1999), as street artists were "confined" in this single place, there was a creative collapse resulted in the dismantling of NOGA.

They were unable to draw their emotions on surfaces considered aseptic or impersonal, something they did spontaneously instead in railway depots, subways and walls. NOGA was dismantled and Fashion Moda was established; Stephan Eins, Jhon Ahearn and Tim Rollins managed to connect the New York subway with the main city galleries. Founded in 1978 in South Bronx, Fashion Moda's function was to be a springboard for all those artists who wanted to be considered more than just writers. Fashion Moda worked and collaborated with many artists. Its main aim was to bring, show, trade and raise awareness of a form of art that was too often despised. The invitation to Documenta 7, held in Kassel in 1982, was fundamental for Fashion Moda: "street art receives official recognition and becomes part of the art world, detaching itself from illegality". (Unknown Author, 2011, s.p.)

In 1983, graffiti was fully integrated into galleries thanks to Sidney Janis, who organized "Post-Graffiti" in his gallery in New York. Among the participants there were Jean Michel Basquiat, Haring, Kenny Scharf and many others. This generation of artists found the way already paved to a new artistic movement. Thanks to a higher interest in graffiti and to the media boom of the time, they managed to build their own career and gain visibility. They also took the opportunity to make graffiti art a common, well-known and praised name. 


\section{The work, the history and its rediscovery}

«One of the most beautiful moments was when Keith requested the creation of a mural outdoors in the place where we considered most appropriate. We thought that he could have painted one side of our huge warehouse, a building located amongst various factories that we rented from the City. » (Jhon Gruen, 2007, p.165)

It's 1986, the year which Haring described as a "crazy year". It's the Crack Is Wack year, the great mural on East Harlem Drive, is the year of Pop Shop, not a shop, but a business and not even an artistic strategy, but a true philosophy on par with the Factory of Warhol.

It was in 1986 at the bistrot in front of the great Stedelijk, the Bodega Keyzer where Haring met Parool Theoder Holman, Dutch writer and journalist. The two exchanged a brief conversation where Haring ended up leaving a small folded napkin. No drawings, no sketch shadows, only three words: Jan van Galenstraat.

Thanks to the collaboration of Chris Reinewald, writer of the online newspaper Longreads, we managed to reconstruct the history of that day. On 5 January 2018, Chris Reinewald (2018) wrote an article on the website of the Stedelijk Museum with the title of "The Dutch adventure of Keith Haring" where it talks about his adventure in Amsterdam. It describes the arrangements made from the beginning with Rini Dippel, head curator of the Stedelijk Museum in 1985, up to the letter [Fig. 1] sent to him by Haring on 25 November in that year to agree on his trip to Holland after his exhibition in Bordeaux.

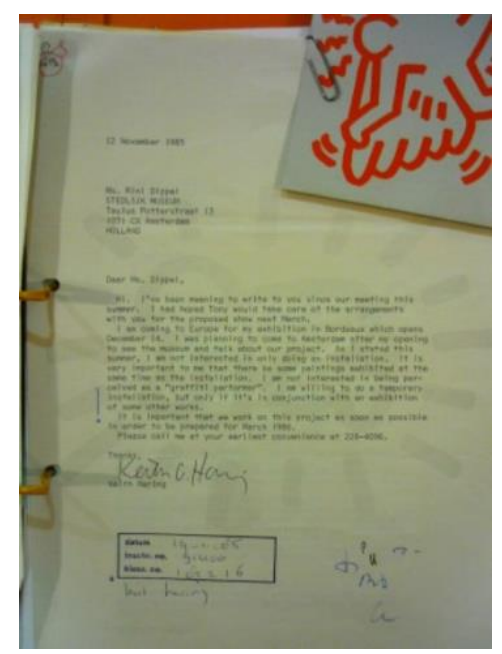

1. Letter by Keith Haring to Mrs Dippel, 12 November 1985, Archives Stedelijk Museum Amsterdam 
And this was how after painting and preparing the great velum 12 × 20 meters long beneath the glass monumental dome and above the historical stairs, on 4 March 1986 he went to the Central Market Markthallen to create of one of his greatest murals. When Haring left the Bodega Keyzer, the art merchant Adrian Venema came in and after learning about what happened to Holman, he painted Haring as an artist destined to fail, to decline over time. Reinewald (2018) wrote that a few days after, accompanied by Dorine Mignot, at that time curator of the Stedelijk Museum and Pieter van Oudheusden, Dutch writer and translator of comic books, Haring went to Jan van Galenstraat where he painted on a north west wall of the art storage facility of that time, the Central Market Markhtallen, shared by the Stedelijk Museum and by the Amsterdam Historisch Museum.

The storage building was then divided by both of the museum institutions mentioned above which divided operating costs in equal parts. For this reason, the Stedelijk Museum did not need to ask for any authorisation to local authorities. Therefore, it was a legal piece of graffiti. The head of business affairs of the Stedelijk Museum planned the painting mural project for 4 March 1986. Haring was given a lift by the firm Boogert which was managed by one of his workers and was used to allow the artist to move in full freedom. Using a large brush and a white paint tub, he started to paint at eleven in the morning and he finished his masterpiece at six o'clock without ever stepping out of the scaffold.

«We prepared the scaffold and Keith started to paint at 11 in the morning. He had already finished at 6 in the afternoon. [...] Once he started to paint, he did not even make the slightest error and never even came down from the scaffold to check the progress of his art piece...» (Gruen, 2007, p.166)

We are talking about a painted surface of more than 12 by 15 meters long. It was Patricia Steur who photographed all the phases of the art creation when she came up on the platform to document the process. Patricia Steur said:

«I witnessed the creation to this immense mural on the outside wall of the storage of the Stedelijk Museum in 1986. It was a gorgeous day in February or March and it was 
exciting to be with him in the hydraulic hoist and witnessing this work of art come to full creation» ${ }^{1}$.

When the work of art was completed, it was signed with three crosses, symbols of the city of Amsterdam and KH86 (Keith Haring 1986). "Later, Wim Beeren, directors of the Stedelijk Museum, called the work of art, Keith's gift to the city" (Reinewald Chris, 2018).

It was like this that thousands of people witnessed the creation of his mythological dog guided by the equally mythological famous man, connotative speaking. Emblematic and characteristic symbol of his art. These were the years in which Haring put particular emphasis on society and on the use of his art for the public and well visible with the only purpose of making people aware of major social themes for dissemination purposes and to make an impact. The work was exhibited only for two years because in 1988 it was covered for practical insulation reasons that had nothing to do with preserving the mural itself. The entire artwork, including the entire structure, was protected and covered by huge metal sheet panels that did not make the artwork visible until 8 June 2018, exactly 30 years later.

Thanks to the collaboration of Aileen Middel and Julia Gruen, we were able to understand how the mural was able to be uncovered. During a radio broadcast interview made on the eleven of October 2017 with the NPO Radio 1 and based on the answers from an interview given personally, we can trace the various steps that led Aileen to rediscover this great work of art. In 2014, Aileen started to get involved with the artwork of Haring after randomly seeing a picture online. She knew about it, but did not remember about the proposed subject. In fact, in one of my interviews, Julia Gruen wrote: "We have known about the mural in Amsterdam for 33 years, since its' creation." (Soliani, 2019, p. 108).

After an in-depth research at the Stedelijk Museum, Aileen found out that the mural was still covered by the sheet metal panel used as cladding for the building. After finding out that the area where the artwork was found was part of a regional redevelopment plan by the firm Ballast Nedam, she battled to uncover the forgotten

\footnotetext{
${ }^{1}$ Extract of the interview with Patricia Steur. Interview conducted on: Soliani, C. (2019). Art in public spaces - Street Art by Keith Haring. (Magistral Thesis). Academy of Fine Arts of Macerata, Macerata, Italia. pp. 109 -110
} 
mural. In 2015, she received an email from Julia Gruen (former director of the Keith Haring Foundation) where she asked about the condition of the mural and was concerned about the fact that the creators of the regional redevelopment project did not really understand the value of Haring's artwork (not in monetary value, but rather its artistic value). From 2017 and on, contacts with the Keith Haring Foundation were intensified until it became the main source of aid, progress and inspiration in the project.

\section{Location and removal of panels}

The artwork is located on the wall of a building in the storage of Markhtallen, today called Food Centre Amsterdam, situated on the north side of Jan Van Galestraat in Amsterdam West. The location is now a huge wholesale market that is not open to the public. It was put to operation in 1934 as a place for the sale and purchase of raw materials in all of Amsterdam.

As previously mentioned, the entire building has completely covered with insulating panels [Fig. 2] in 1988 to address the issue of improper insulation that was causing serious damages to the artworks kept inside (is worth noting that the facility was used to store the artworks of the Stedelijk and History Museum).

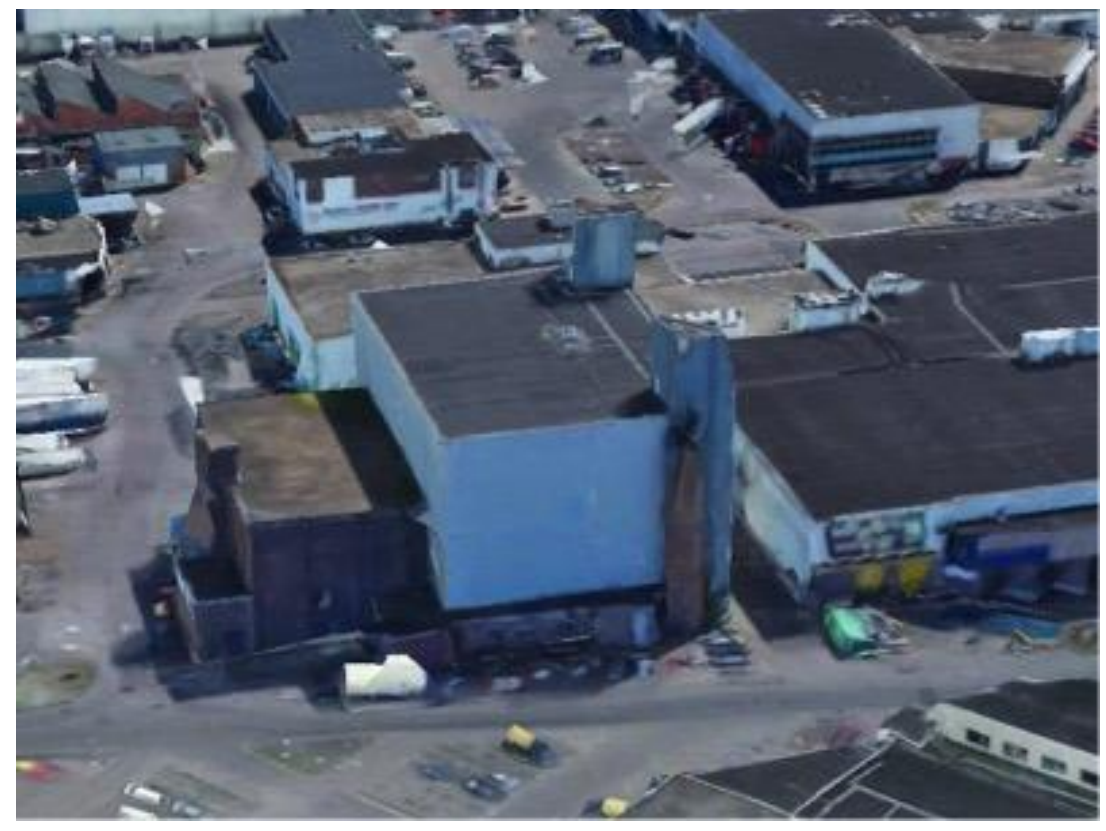

2. Building covered with sheet metal panels before their removal. Google Earth View 
The insulating panels covered the artwork until 8 June 2018 when along with the creators of the redevelopment project Ballast Nedam (Danish firm in charge of redeveloping public areas), the Relationship Manager of the Stedelijk Museum, Sofia Patat, as well as the restorers Antonia Rava, Willing Shank and artist Aileen Esther Middel, the panels were removed only on the west side of the building.

A company equipped with a mobile boom blasted the panels from their supports, for a total of about 70 panels. In this manner, it was obvious that the panels were anchored to nine cross bars fixed to the wall with metal joints. The metal joints where the bars where positioned above were applied even above the paint film. The removal operation lasted 4 days and at the end the metal bars along with the joints were removed and once again the artwork can be admired in its full splendour [Fig. 3].

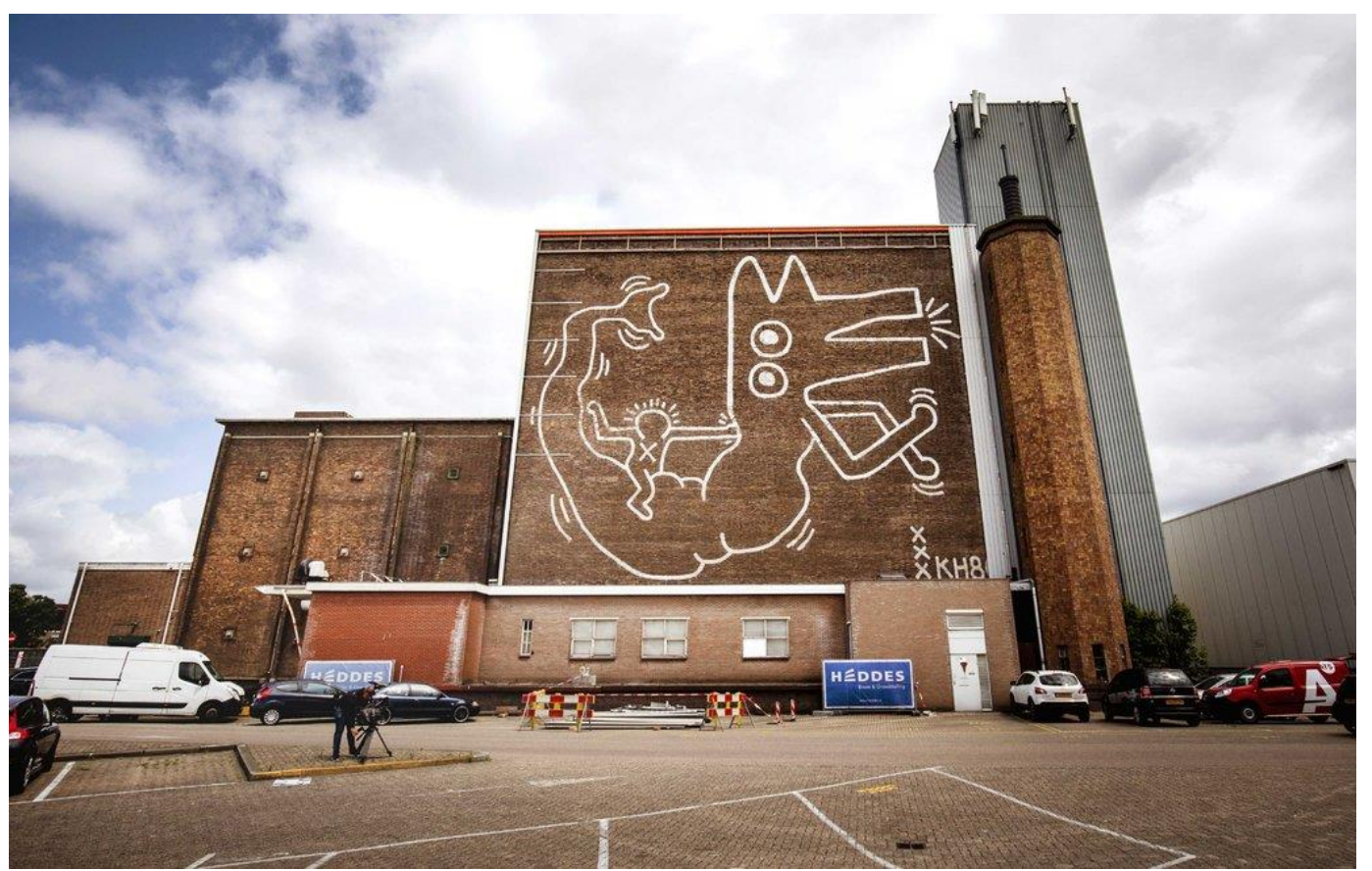

3. Mural by Keith Haring after the removal of the metal panels | CREMKOO DE WAAL / EPA-EFE / REX / Shutterstock

As it was created in 1986, the year of Crack is Wak and the mural of Berlin, we can say that the monster shows the disease (AIDS) and that the man riding it was dominating its influence and aggressiveness in an artistic manner to show that destruction can be controlled. Another interpretation was given by Diana Ozon during a private interview where she wrote:

«- He never said you what the mean of his drawing? 
[...] I can only guess what it means. I see the fish-dog on the marketwall as a huge fish that transported him across the ocean to the dogs-city which Amsterdam was at that time. Or maybe he heard and saw the dog activity at the other site of the canal - a park like strip of green- maybe he saw the big fishes on the foodmarket»². (Soliani, 2019, pp. 99-100)

\section{Conservation condition}

The artwork was found in good conservation conditions when the panels were removed from the wall. From a closer look, after going up on the mobile boom, it was confirmed that the paint film was actually not all that great. There were various chips on the paint in nearly all the artwork, mainly concentrated in the upper central part of the drawing (the head and upper lines of the man's arms, the inner line of the tail and the inner part of the animal's neck). [Fig. 4]

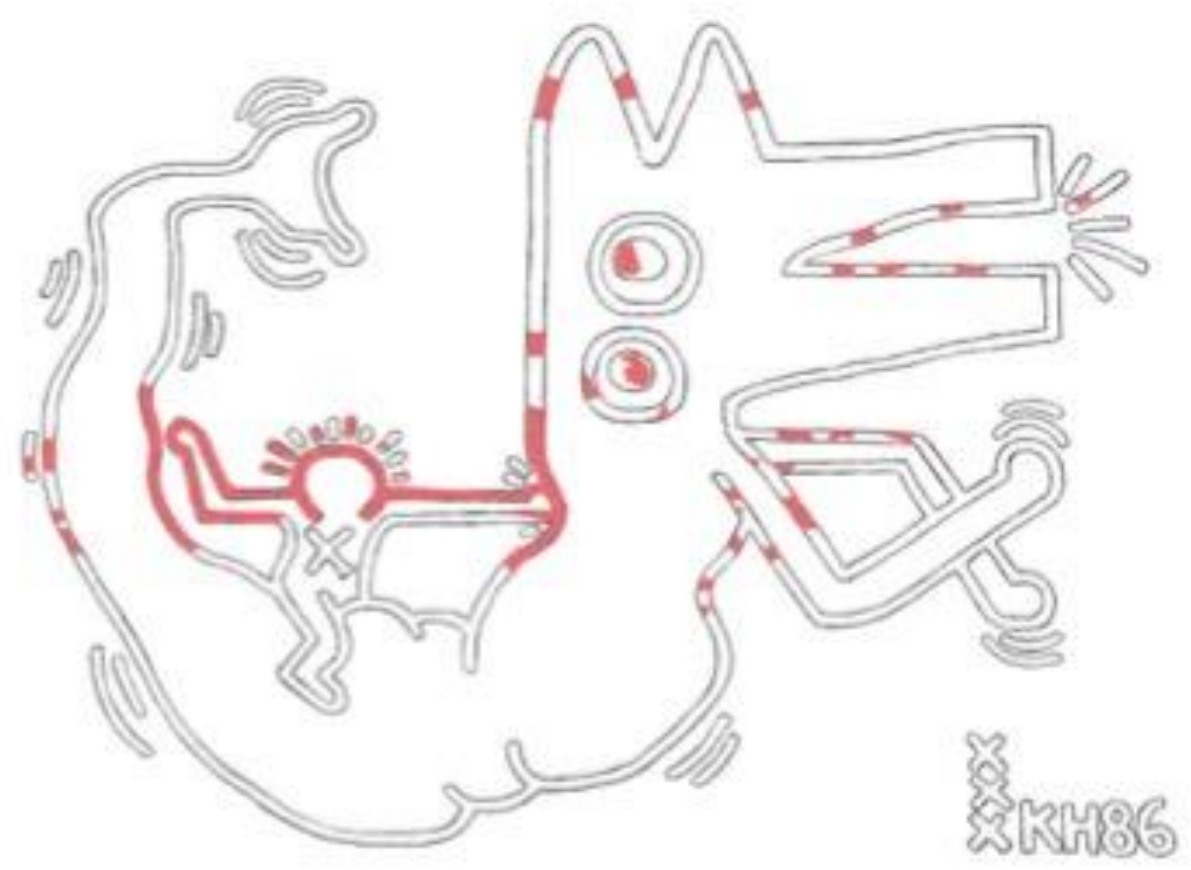

4. An outline of the damaged areas of the artwork

${ }^{2}$ Extract of the interview with Diana Ozon. Interview conducted on: Soliani, C. (2019). Art in public spaces - Street Art by Keith Haring. (Magistral Thesis). Academy of Fine Arts of Macerata, Macerata, Italia. pp. $99-100$ 
The following could be seen immediately: No background was prepared for the mural, the paint film was placed over a dirty surface and there were paint particles more pronounced than others.

It must be noted that Haring worked only that one day which was humid and rainy. After an in-depth research, a picture of the artwork was found in which it showed the artwork before being covered by the insulating panels and right after the creation of the artwork. Based on the pictures found ${ }^{3}$, we can see the various spots or bright spots that affect and match with part of the drawing that was damaged the most in the paint film. It could be reasonably the fact that the paint in these parts did not adhere properly due to the fact that the wall was wet.

\section{The restoration proposal}

The restoration proposal is aimed at identifying those products that could be used in view of an imminent in-situ work. It was agreed to make subsequent phases starting from a historic/artistic research until reaching a scientific and chemical analysis. The initial ideologies can be kept or modified based on the knowledge gained gradually. Team work will be based on the fulfilment of mutual needs, having as priority the obtainment of results in real time for the artwork by integrating the various scientist professional roles, the historian and the restorer and hence dividing the final decision of the intervention.

Given the issues with the support and paint, the following was suggested:

- Nano ESTEL, as consolidating and fixing product of the brick and film paint interface

- Floline A, as adhesive product for film paint

- Siox-5, as water-repellent protective product to be applied only on the paint film

It being an atypical study, it is advisable to test the selected products on ad-hoc specimens to evaluate their effectiveness.

\footnotetext{
${ }^{3}$ The original pictures of Patricia Steur are found in the thesis paper. Soliani, C. (2019). Art in public spaces - Street Art by Keith Haring. (Magistral Thesis). Academy of Fine Arts of Macerata, Macerata, Italia. pp. 111 - 113
} 


\section{Conclusions}

Starting from a historical and artistic research on street art movement, the goal of this study is to understand the reason why this innovative art is considered, perhaps and in some cases, the last avant-garde. Street art ranges from markers, spray cans, large canvases, portions of walls and even videos. It does not require a real method, no technical ability is necessary to perform it. The more different and nonconformist the artists, the greater the "movement". We understand, however, that graffiti is a different and parallel art, a too unconventional one and therefore, most of the times, considered illegal.

Keith Haring has been the promise kept by all these new institutions. By devoting himself to art since he was a child, he managed to unhinge the fundamental dogmas of conventional art, creating new forms and making them his own expression. Throughout his whole life he was active as an artist and as a man; he worked with adults and children trying to gain visibility and to make them accept a movement and a form of art declared unconventional and atypical.

The proposed paper was suitable in identifying the physical condition of the artwork, it being understood as a new rediscovery of it in the world of art. Even if major researchers and art lovers knew of its existence, its meaning and presence was unknown to many. Given the special conditions in so far it concerns the artwork, the team was asked for a possible restoration proposal in which the term considered the individual parts of the artwork, starting from the substrate up to the paint film. This is how after various consultations with the respective producers, three products were chosen that are suitable for a hypothetical in-situ restoration. By considering the atypical study case, an effort was made to bring together application and preservation qualities in these products that could have an optimal result as far as the exposure of the artwork to the outside environment and a sound efficiency in their individual attributes of: consolidation, adhesion and protection.

By studying the iconography of the painting, the historical matters associated with it, the commissioner and the biography of the artist, but most of all the exchange of brief, but major interviews with the collaborators allows us to rediscover and assemble a new small piece "mosaic", immense as the history of art. 


\section{Bibliography}

Barbieri Deva, Alessandro \& Mininno, Alessandro. (2009). Come ti viene in mente di fare graffiti?. Retrieved from: (https://issuu.com/laroba/docs/010_per-web)

Ciotta, Ennio. (2012). Street art. (pp. 7- 10) Lecce: Bepress Edition.

Goldstein, Richard (1973). “The Graffiti 'Hit' Parade”, New York Magazine, March 26, 34-39

Gruen, Jhon. (2007). Keith Haring. La biografia. (p. 165). Milano: Dalai Editore.

Iovane, Giovanni. (1999). Pittura dura. Dai graffiti alla street art. Exhibition catalogue (Torino, palazzo Bricherasio, 20 novembre 1999-30 gennaio 2000). Electa. p.20

Reinewald, Chris. (2018, January 15). The Dutch adventures of Keith Haring. Stedelijk Museum Amsterdam. Retrieved from: (https://www.stedelijk.nl/en/digdeeper/dutchadventures-keith-haring)

Riva, Davide. (2007). Introduction. In A. Tinelli (Ed.), Street Art Sweet Art. dalla cultura hip hop alla generazione pop up (pp. 30-31). Skira.

Soliani, Caterina. (2019). Art in public spaces - Street Art by Keith Haring. (Magistral Thesis). Academy of Fine Arts of Macerata, Macerata, Italia

Stewart, Jack. (2009). Graffiti Kings: New York Mass Transit Art of the 1970s (pp. 6062). Harry N Abrams Inc.

Unknown Author. (2011, February, 2018). Gallerie e street art: le origini. About Graffiti Art \& More. Retrieved from: (http://aboutgraffitiartmore.blogspot.com/2011/02/galleriee-street-art-le-origini.html) 